Bangladesh J. Bot. 47(4): 831-837, 2018 (December)

\title{
EFFECTS OF RHIZOBIAL NOD FACTORS (LIPO CHITOOLIGOSACCHARIDE) ON SEEDLING GROWTH OF MAIZE (ZEA MAYS L.) UNDER SALT STRESS
}

\author{
D UdHAYA NANDHINI* AND E SOMASUNDARAM \\ Department of Sustainable Organic Agriculture, Tamil Nadu Agricultural University, \\ Coimbatore-641 003, Tamil Nadu, India
}

Keywords: Nod factors, Lipo chitooligosaccharide, Salt stress, Seedling growth, Amylase, Reducing sugars

\begin{abstract}
Effects of nod factors (lipo chitooligosaccharide) on seedling growth of maize under salt stress have been studied. The study was framed with seed priming using lipo chitooligosaccharide (LCO) a nod factor (a) $4 \mathrm{ml} / \mathrm{kg}$ of seeds and without priming on maize seedling growth which was exposed to different levels of salinity $(0,2,4,6,8$ and $10 \mathrm{dS} / \mathrm{m})$. Salinity negatively influenced the seedling growth of maize. However nod factor treated maize seedlings had relatively higher germination percentage, root length, shoot length, reducing sugars and amylase activity. Correlation analysis revealed positive relationships between seedling growth parameters. Thus, seed priming with nod factor $(4 \mathrm{ml} / \mathrm{kg})$ improved the resistance to salinity at seedling stage. $\mathrm{NaCl}$ concentrations restricted amylase enzyme activity and reducing sugar content in the germinating seeds. Priming of nod factor/LCO mitigated the restricted effects of salinity on amylase activity and reducing sugars.
\end{abstract}

\section{Introduction}

Salinity is a serious problem around the world, which affects agricultural productivity in many arid and semi-arid regions. Arid, semi-arid and coastal regions of sub-humid areas around the world are salt-affected and reported to have lower in economic produce of crop (IAEA 1995). Soil salinity is a major extensive problem in India which includes 8.1 million hectares out of the total 143 million hectares of cropping area and one lakh hectares in Tamil Nadu. Salinity and water logging are continuously causing reduction in the cultivated land size every year.

Maize is one of the third most significant cereals which are grown predominantly under various environmental conditions of the world and is a salt sensitive crop. In India, maize is virtually most important cereal after wheat and rice is cultivated on about 71 million hectares with a production of about 22.26 million tons and an average yield of $2476 \mathrm{~kg} / \mathrm{ha}$ (Anon. 2014). It is consumed as prime food and commonly fed to the livestock. Improvement in establishment characteristics of maize has received considerable attention around the world, particularly in salt affected soils.

Germination is a very sensitive phase to salinity that reduces the water absorption. In the recent decade, different strategies are being evolved for solving the adverse effects of salinity such as screening of germplasm of different crop plants, seed treatment with stress alleviating substances. Seed priming is one of the biochemical methods that enhances seed performance and provides better germination under adverse conditions. This presowing seed management techniques, where the seeds are partially soaked and subsequently dried back for invigorative effect that expresses on field emergence and extended up to yield.

Microorganisms and plants have the ability to synthesize a large number of organic compounds of enormous chemical diversity. Rhizobial bacteria from the family Rhizobiaceae (i.e.,

*Author for correspondence: <udhaya.jeni@gmail.com>. 
rhizobia) affect fundamental processes in plants by producing signal molecules, lipochitooligosaccharides (LCOs), during the establishment of the rhizobia-legume nitrogen fixing symbiosis. These compounds, known as nodulation factors (Nod factors), are complex, with activity at concentrations as low as picomolar (Spaink 1996).

Although this process occurs naturally over time in legumes, agricultural procedures have been developed to begin the process earlier. It has been shown that LCOs can stimulate several physiological responses in non-host plants including cell division (Egertsdotter and Von Arnod 1998). Application of Nod factors to seeds of legumes and non-legumes stimulates germination, seedling emergence, plant growth and yield in crop and horticultural plant species (Ferguson and Mathesius 2003). Nod factors have recently been shown to also enhance the germination, growth and yield of legumes and non-legumes through processes other than nodulation (Prithiviraj et al. 2003). Priming with lipo-chitooligosaccharides (nod factors) has been emerged as a new trend of this decade which is a unique molecule and recently considered to have a hormone like substances. The main aim of the present work was to find out the impression of LCO priming on the saline tolerance of maize which may be useful for future salinity research works.

\section{Materials and Methods}

Seeds of maize hybrid (CoHM 6) were used and research was conducted in a laboratory of the Department of Seed Sciences and Technology, Tamil Nadu agricultural University, Coimbatore. . The seeds were primed by soaking with LCO@ $9 \mathrm{ml} / \mathrm{kg}$ of seed for $12 \mathrm{hr}$ at room temperature. A factorial CRD was used with 2 factors which are salinity at 6 levels $(0,2,4,6,8$ and $10 \mathrm{dS} / \mathrm{m}$ ) and 2 levels of priming (LCO primed and nonprimed seeds). The experiment was carried out in 48 Petri dishes that are 24 for $\mathrm{NaCl} \mathrm{LCO}$ primed seeds and 24 for unprimed (Control) seeds. The salinity levels were obtained by dissolving 1.28, 2.56, 3.84, 5.12, $6.4 \mathrm{~g}$ of $\mathrm{NaCl}$ in one litre distilled water, respectively. Control was employed as distilled water $(0 \mathrm{dS} / \mathrm{m})$. Seeds were sown on $10 \mathrm{~cm}$ dia Petri dishes which was lined with whatman No1. filter paper and these were provided with $10 \mathrm{ml}$ from each treatment solution daily. Germination count was recorded after $48 \mathrm{hrs}$ of sowing daily, and ended when no promotion of germination happened.

Mean shoot and root lengths toward the end of germination were measured from every replication. Dry weights of seedlings were measured with the assistance of an electric adjust in the wake of drying every replication at $70^{\circ} \mathrm{C}$ in the oven to get the steady weight (Afzal et al. 2005).

Around $4 \mathrm{~g}$ of cotyledons (with in place embryonic axis) were homogenized with $20 \mathrm{ml}$ of sodium phosphate buffer, $\mathrm{pH}$ 7.5. The homogenate was vortexed and centrifuged for $10 \mathrm{~min}$ at $20,000 \mathrm{~g}$ and the supernatant was gathered. The measure of reducing sugars (Henson and Stone 1988) amylase action (Bernfeld 1955) present in the seed concentrates was resolved.

\section{Results and Discussion}

The seed treatment of LCO and salinity significantly affect the seedling growth of maize. Data with respect to the germination percentage of maize at distinctive saltiness levels uncovered that germination percentage of plants was inversely related with increment in salinity (Table 1). Distinction in germination percentage at diverse saline levels was profoundly remarkable. Treatment means showed that highest germination percentage (66) was in control while least (33) in $10 \mathrm{dS} / \mathrm{m}$, therefore a decline with dynamic increment saline levels was found (Carpici et al. 2009). Saltiness versus LCO priming association showed that control displayed the highest germination percentage (79) trailed by $2 \mathrm{dS} / \mathrm{m}$ while least 49 germination was noted in $10 \mathrm{dS} / \mathrm{m}$. The reason for reduction in germination under salinity is due to the reduction of water potential in the medium which inhibited water intake that played a critical role in the initiation of activity of 
the enzyme $\alpha$-amylase. Salinity caused reduction in germination percentage up to 52 and 63 per cent at higher $\mathrm{NaCl}$ level ( 8 and $10 \mathrm{dS} / \mathrm{m}$ ), respectively in maize. But, the detrimental effect was lower at lower concentration and higher at higher concentration (Kaymakanova 2009).

However, the performance of the bioprimed seed was better in all the $\mathrm{NaCl}$ concentrations compared to the nonprimed seed. LCO effect was significant on seed germination. The increase in germination over nonprimed seeds accounted for 13, 29, 32, 36, 39 and 45 per cent under $0,2,4$, 6,8 and $10 \mathrm{dS} / \mathrm{m} \mathrm{NaCl}$ salt concentrations. Seed germination was significantly faster in LCO treated seeds than those in control seeds.

The increase in emergence percentage in seeds primed with nod factor under saline conditions may be due to LCO evoked in cell division movement which upgraded oxygen uptake, expanded $\alpha$ - amylase action and the effectiveness of assembling nutrients from the cotyledons to the embryonic axis (Daychok et al. 2000).

From statistical examination, it is apparent that length of root and shoot was essentially controlled by a progressive increment in salinity of maize hybrid (Table 1). At lower level (0 $\mathrm{dS} / \mathrm{m}$ ) of salt treatment relatively less reduction in root and shoot length was observed and the higher salinity $(10 \mathrm{dS} / \mathrm{m})$ exhibited a significant reduction in seedling growth both for primed and non primed seeds. When seedlings were non primed, maximum shoot and root length (16.8 and $8.1 \mathrm{~cm})$ was attained by control $(0 \mathrm{dS} / \mathrm{m})$ and minimum was observed $(1.2$ and $3.65 \mathrm{~cm})$ in 10 $\mathrm{dS} / \mathrm{m}$ (Table 1). In LCO primed seeds, control $(0 \mathrm{dS} / \mathrm{m})$ exhibited the top most value (14 and 23.2 $\mathrm{cm})$ while the lowest was recorded $10 \mathrm{dS} / \mathrm{m}$.

Table 1. Nod factors influence on mean germination percentage, root length, shoot length of maize under different levels of salinity.

\begin{tabular}{|c|c|c|c|c|c|c|c|c|c|}
\hline \multirow{2}{*}{$\begin{array}{l}\text { Salinity } \\
(\mathrm{dS} / \mathrm{m})\end{array}$} & \multicolumn{3}{|c|}{ Germination percentage } & \multicolumn{3}{|c|}{ Shoot length $(\mathrm{cm})$} & \multicolumn{3}{|c|}{ Root length $(\mathrm{cm})$} \\
\hline & $\mathrm{P}$ & NP & Mean & $\mathrm{P}$ & NP & Mean & $\mathrm{P}$ & NP & Mean \\
\hline 0 & $79(96)$ & $66(83)$ & $73(90)$ & 23.2 & 16.8 & 20.0 & 13.9 & 8.1 & 11.0 \\
\hline 2 & $73(91)$ & $54(64)$ & $63(78)$ & 21.1 & 14.1 & 17.6 & 11.9 & 6.1 & 9.0 \\
\hline 4 & $66(83)$ & $49(56)$ & $57(69)$ & 20.1 & 12.6 & 16.3 & 11.4 & 5.1 & 8.2 \\
\hline 6 & $59(73)$ & $43(46)$ & $51(60)$ & 18.6 & 11.8 & 15.2 & 10.3 & 6.0 & 8.2 \\
\hline 8 & $54(65)$ & $39(40)$ & $46(52)$ & 14.2 & 7.70 & 10.9 & 6.0 & 2.9 & 4.5 \\
\hline 10 & $49(57)$ & $33(31)$ & $42(44)$ & 9.95 & 3.65 & 6.80 & 3.1 & 1.2 & 2.2 \\
\hline Mean & $63(78)$ & $47(54)$ & & 17.8 & 11.1 & & 9.4 & 4.9 & \\
\hline SEd & 0.93 & 1.61 & 2.27 & 0.28 & 0.49 & 0.69 & 0.24 & 0.42 & 0.59 \\
\hline $\mathrm{CD}(\mathrm{p}=0.05)$ & 1.88 & 3.25 & NS & 0.58 & 1.00 & NS & 0.49 & 0.85 & 1.20 \\
\hline
\end{tabular}

Values in parenthesis are original values of germination percentage. P- Priming and NP- non priming

There was a significant decrease in the length of root and shoot at higher levels of salinity when compared with control. At the severe stress level of $10 \mathrm{dS} / \mathrm{m}$, the response of maize was differential. Control showed significantly increased root and shoot length when compared to other salinity levels. The salinity level of $10 \mathrm{dS} / \mathrm{m}$ had a significantly reduced root and shoot length percentage of 63 and 61 over control in non primed seeds. The decline in root growth under salt stress condition was attributed to the inhibition of hydrolysis of endosperm reserves and reduced translocation of food reserves from endosperm to embryo (Panneerselvam et al. 1998). Water 
content of the seedlings decreased with increasing salt concentration. Osmotic effects of salt on plants are the result of lowering of the soil water potential due to increase in solute concentration in the root zone. In the present investigation there is regular decline in the root and shoot length, with increase in salinity levels. This observation is more or less similar to previous findings (Osorio et al. 1998).

There was a significant increase in the total length of the roots and shoots with priming of LCO. The root and shoot lengths of LCO primed seeds were 28 and 42 than non primed seeds in control. This might be due to enhanced germination and seedling growth, along with the mitogenic nature of LCOs, suggests accelerated meristem activity which induces the root growth (Souleimanov et al. 2002).

The fresh weight of roots and shoots reduced significantly as the levels of salinity expanded from $0-10 \mathrm{dS} / \mathrm{m}$ (Table 2). Maximum root and shoot fresh weight was observed in control, while, it was minimum at highest salinity level. Maximum root and shoot fresh weight (3.4 and $5.2 \mathrm{~g}$ ) was observed in $0 \mathrm{dS} / \mathrm{m}$ while minimum ( 0.02 and $0.63 \mathrm{~g}$, respectively) was recorded $10 \mathrm{dS} / \mathrm{m}$ followed by $8 \mathrm{dS} / \mathrm{m}$. Thus, LCO primed seeds are ended up being salt tolerant having a value of 6.8 and $9.4 \mathrm{~g}$. From the means, it is clear that the range of fresh weight of root and shoot was fluctuated from $6.8 \mathrm{~g}$ and $9.4 \mathrm{~g}(0 \mathrm{dS} / \mathrm{m})$ to $0.8 \mathrm{~g}$ and $3.23 \mathrm{~g}(10 \mathrm{dS} / \mathrm{m})$ respectively.

Table 2. LCO on root fresh weight, root fresh weight, root dry weight and shoot dry weight of maize under different levels of salinity.

\begin{tabular}{|c|c|c|c|c|c|c|c|c|c|c|c|c|}
\hline \multirow[t]{2}{*}{$\begin{array}{l}\text { Salinity } \\
(\mathrm{dS} / \mathrm{m})\end{array}$} & \multicolumn{3}{|c|}{$\begin{array}{l}\text { Root fresh weight } \\
\text { (g) }\end{array}$} & \multicolumn{3}{|c|}{$\begin{array}{l}\text { Shoot fresh weight } \\
\text { (g) }\end{array}$} & \multicolumn{3}{|c|}{$\begin{array}{l}\text { Root dry weight } \\
\text { (g) }\end{array}$} & \multicolumn{3}{|c|}{$\begin{array}{l}\text { Shoot dry weight } \\
\text { (g) }\end{array}$} \\
\hline & $\mathrm{P}$ & NP & Mean & $\mathrm{P}$ & NP & Mean & $\mathrm{P}$ & NP & Mean & $\mathrm{P}$ & $\mathrm{NP}$ & Mean \\
\hline 0 & 6.80 & 3.40 & 5.10 & 9.40 & 5.20 & 7.30 & 1.30 & 1.10 & 1.20 & 3.42 & 1.33 & 2.38 \\
\hline 2 & 5.97 & 2.68 & 4.33 & 8.55 & 4.00 & 6.28 & 1.04 & 0.84 & 0.94 & 2.90 & 1.10 & 2.00 \\
\hline 4 & 4.53 & 0.83 & 2.68 & 7.53 & 2.63 & 5.08 & 0.65 & 0.45 & 0.55 & 2.33 & 0.73 & 1.53 \\
\hline 6 & 3.52 & 1.03 & 2.28 & 5.48 & 1.58 & 3.53 & 0.31 & 0.27 & 0.29 & 1.58 & 0.64 & 1.10 \\
\hline 8 & 1.47 & 0.55 & 1.01 & 4.28 & 1.18 & 2.73 & 0.10 & 0.10 & 0.10 & 1.05 & 0.23 & 0.64 \\
\hline 10 & 0.80 & 0.22 & 0.51 & 3.23 & 0.63 & 1.93 & 0.03 & 0.02 & 0.02 & 0.35 & 0.09 & 0.22 \\
\hline Mean & 3.85 & 1.45 & & 6.41 & 2.53 & & 0.57 & 0.46 & & 1.94 & 0.68 & \\
\hline SEd & 0.18 & 0.31 & 0.44 & 0.18 & 0.32 & 0.45 & 0.04 & 0.07 & 0.10 & 0.10 & 0.18 & 0.25 \\
\hline $\mathrm{CD}(\mathrm{p}=0.05)$ & 0.36 & 0.63 & 0.88 & 0.37 & 0.64 & NS & 0.08 & 0.15 & NS & 0.21 & 0.36 & 0.51 \\
\hline
\end{tabular}

Root and shoot dry weight of maize hybrid showed a decline towards increment in salinity level (Table 2). Control displayed maximum root and shoot dry weight values i.e., 1.3 and $3.43 \mathrm{~g}$ both for LCO primed and non primed seeds, respectively, while minimum $(0.03$ and $0.35 \mathrm{~g})$ was recorded in $10 \mathrm{dS} / \mathrm{m}$ at higher level of salinity. In LCO primed seeds maximum (1.3 g) was recorded in $0 \mathrm{dS} / \mathrm{m}$ while minimum $(0.03 \mathrm{~g})$ was observed in $10 \mathrm{dS} / \mathrm{m}$. From the data it is evident that LCO primed seeds were relatively salt tolerant to varied levels of salinity.

Results show that maize sensitiveness to salinity differed significantly in all of the observed parameters, including reduction in shoot lengths, fresh weight and dry weight of shoots and roots in response to salinity stress. A decrease in root dry mass may be brought about by the reduced nutrients transportation from the soil to the developing shoots. Hence, a decline in shoot dry mass accompanied by a decrease in root dry matter is a normal growth process under salt stress. The 
reason for relative increase in LCO primed seeds is indirectly affect photosynthesis by inducing sink strength. Nod factors are strong inducer of cell division through the induction of cell cycle genes in plants.

The activity of amylase was high in the control seeds which were exposed to distilled water when contrasted with all the saltiness levels (Fig. 1). Previously decrease in amylase activity was reported in the distinctive levels of salinity by Mei and Song (2008). This reduction in amylase activity was seen on all the four observations considered for study. The amylase activity was found to reduce drastically $(0.128,0.265,0.386$ and 0.512 for $12,24,36$ and $48 \mathrm{hrs}$, respectively) in the seeds grown under $10 \mathrm{dS} / \mathrm{m}$. The activity of amylase in the seeds exposed to LCO was high when compared to the non primed seeds in all the salt concentrations. There was a gradual increase in amylase activity in LCO primed seeds as observed with non primed seeds. Over the span of germination a positive relationship was seen with movement of amylase which was noteworthy (Fig. 2). The measure of diminishing sugars was less in the non prepared seeds for diverse centralization of sodium chloride.

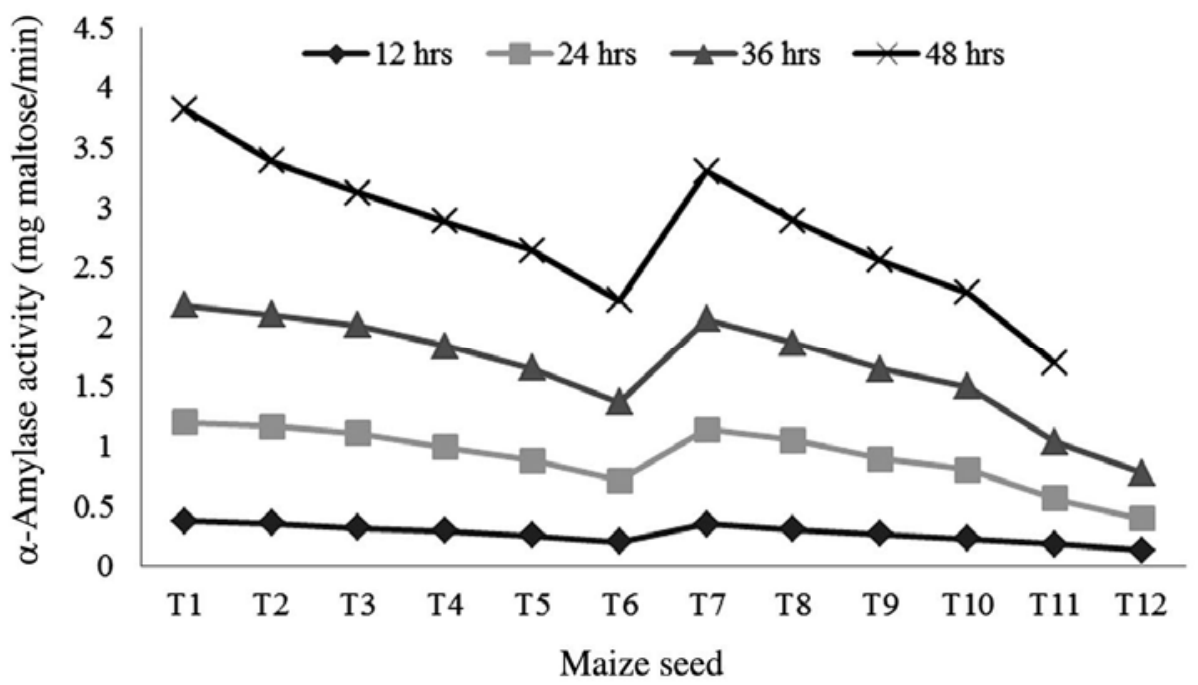

Fig. 1. Nod factor influence on $\alpha$-Amylase activity (mg maltose/min) of maize seed under salt stress.

The activity of amylase was higher in control compared to all the treatments. Salt concentrations without priming reduced the activity of amylase and higher reduction was observed in $10 \mathrm{dS} / \mathrm{m}$ concentration on all the four observations considered for the study (Sidari et al. 2008). Seeds exposed to LCO were found to have relatively more activity of amylase under control followed by $2 \mathrm{dS} / \mathrm{m}$. There was a relative increase in enzyme activity with LCO primed seeds under various salt concentrations. The decrease in the activity of amylase followed may be ascribed to the osmotic adjustment by the sugars as a reaction to salinity impelled water shortage.

The content of reducing sugars in the control and exposed to salinity was found to have increased $(0.55,0.73,0.80$ and 0.96 for $12,24,36$ and $48 \mathrm{hrs,} \mathrm{respectively} \mathrm{for} \mathrm{LCO} \mathrm{priming)} \mathrm{over}$ the period of germination and a positive correlation was observed with the activity of amylase which was significant (Fig. 2). The amount of reducing sugars was less in the non primed seeds for different concentrations of sodium chloride Zheng et al. 2018). The decrease in reducing sugar content was very high $(0.08,0.12,0.19$ and 0.26 for $12,24,36$ and $48 \mathrm{hrs}$, respectively) in the 
seeds exposed to high concentration of sodium chloride (10 dS/m) (Othman et al. 2006). The amount of reducing sugars in the seeds treated with LCO was high when compared to non primed seeds.

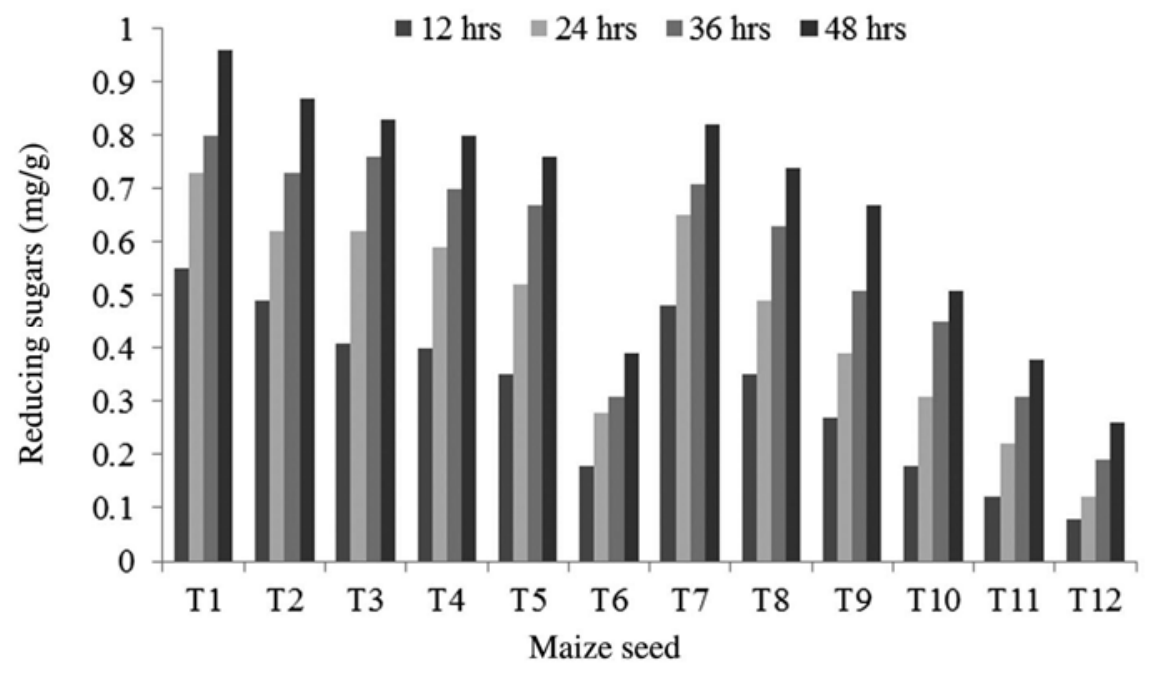

Fig. 2. Nod factor influence on reducing sugars $(\mathrm{mg} / \mathrm{g})$ of maize seed under salt stress.

The increase in reducing sugars during the three different hours of germination was significant. Relative increment in reducing sugar content was noticed in seeds exposed to LCO for all salt concentration over the period of germination. The amount of reducing sugars was less in the non primed seeds with different concentration of sodium chloride. The reduction in content of reducing sugar was very high in the seeds exposed to high concentration of sodium chloride (10 $\mathrm{dS} / \mathrm{m}$ ). This emphasizes that the carbohydrate metabolism was adjusted the osmosis in shoot and root at increasing concentrations of $\mathrm{NaCl}$.

Proactive measures like seed priming for adaptation to salt stress can substantially reduce many adverse impacts, and thus contribute to sustained production of the rural population. Based on the outcome of the present work, it is evident that priming the maize seeds with LCO enhances the germination under saline stress conditions. However the mode of action of salt tolerance by LCO at initial stage needs further investigation.

\section{Acknowledgements}

Authors are indebted to M/s Novozymes South Asia Private Ltd., Bengaluru for financially supporting this research work.

\section{References}

Abdul Jaleel C, Gopi R, Sankar B, Manivannan P, Kishorekumar A, Sridharan R and Panneerselvam R 2007. Studies on germination, seedling vigour, lipid peroxidation and proline metabolism in Catharanthus roseus seedlings under salt stress. South Afr. J. Bot. 73: 190.

Afzal I, Basra SMA and Iqbal A 2005. The effects of seed soaking with plant growth regulators on seedling vigour of wheat under salinity stress, J. Stress Physiol. Biochem. 1(1): 6-14.

Anonymous 2014. Ministry of Agriculture, 2014-15. 2014. www. agricoop.nic.in. 
Bernfeld P 1955. Amylase, $\alpha$ and $\beta$. In: Methods in Enzymology. Colowick SP New York. pp. 149.

Carpici EB, Celık N and Bayram G 2009. Effects of salt stress on germination of some maize (Zea mays L.) cultivars. African Journal of Biotechnology 8(19): 4918-4922

Daychok JV, Tobin AE, Price NPJ and Von Arnold S 2000. Rhizobial nod factor stimulate somatic embryo development in Picea abies. Plant Cell Rep. 19: 290-297

Egertsdotter U. and Von Arnod S 1998. Development of somatic embryos in Norway spruce. J. Exp. Bot. 49:155-62.

Ferguson and Mathesius. 2003. The mechanisms for Nod factor effects. J. Plant Gr. Regul. 22: 47-55.

Henson CA and Stone JM 1988. Variation in a-amylase and a-amylase inhibitor activities in barley malts. J. Cer. Sci. 8: 39-45.

IAEA 1995. Management strategies to utilize salt affected soils. IAEA-TECDOC-814, Soil fertility, Irrigation and crop production section, Joint FAO/IAEA Division of nuclear techniques in food and agriculture, Vienna, Australia.

Jamil M, Lee DB, Jung KY, Ashraf M, Lee SC and Rha ES 2006. Effect of salt ( $\mathrm{NaCl})$ stress on germination and early seedling growth of four vegetables species. J. Central Eur. Agric. 7: 273-283.

Kaymakanova M 2009. Effect of salinity on germination and seed physiology in bean (Phaseolus vulgaris L.), XI Anniversary Scientific Conference. Biotechnol Biotechnol Equip. 23: 326-329.

Mei Y and Song S 2008. Early morphological and physiological events occurring during germination of maize seeds. Agric. Sci. China 7: 950-957.

Osorio J, Osorio ML, Chaves MM and Pereira JS 1998. Water deficits are more important in delaying growth than in changing patterns of carbon allocation in Eucalyptus globulus. Tree Physiology 18: 363-373.

Othman Y, Al-Karaki G, Al-Tawaha AR and Al-Horani A 2006. Variation in germination and ion uptake in barley genotypes under salinity conditions. World J. Agric. Sci. 2: 11-15.

Panneerselvam R, Muthukumarasamy M and Rajan SN 1998. Amelioration of Nacl Stress by triadimefon in soybean seedlings. Bio. Plant. 41(1): 133-137.

Prithiviraj B, Zhou X, Souleimanov A, Wajahatullah MK and Smith DL 2003. A host specific bacteria-toplant signal molecule (Nod factor) enhances germination and early growth of diverse crop plants. Planta. 216: $437-445$.

Sidari M, Santonoceto C, Anastasi U, Preiti G and Muscolo A 2008. Variations in four genotypes of lentil under NaCl-salinity stress. Am. J. Agric. Biol. Sci. 3: 410-416.

Siddiqui ZS and Khan MA 2011. The role of enzyme amylase in two germinating seed morphs of Halopyrum mucronatum (L.) Stapf. in saline and non-saline environment. Acta Physiologiae Plantarum, 33: 1185-1197.

Souleimanov A, Prithiviraj B and Smith DL 2002. The major Nod factor of Bradyrhizobium japonicum promotes early growth of soybean and corn. J. Exp. Bot. 53: 1929-1934.

Spaink HP 1996. Regulation of plant morphogenesis by lipo-chitin oligosaccharides. Crit. Rev. Plant Sci. 15: 559-82.

Zheng Y, Jia A, Ning T. Xu J, Li Z and Jiang G 2008. Potassium nitrate application alleviates sodium chloride stress in winter wheat cultivars differing in salt tolerance. J. Plant Physiol. 165: 1455-1465. 